\title{
Correlation between apparent diffusion coefficient (ADC) and cellularity is different in several tumors: a meta-analysis
}

\author{
Alexey Surovi, ${ }^{1,}$, Hans Jonas Meyer $^{1, *}$ and Andreas Wienke ${ }^{2, *}$ \\ ${ }^{1}$ Department of Diagnostic and Interventional Radiology, University of Leipzig, Leipzig, Germany \\ ${ }^{2}$ Institute of Medical Epidemiology, Biostatistics, and Informatics, Martin-Luther-University Halle-Wittenberg, Halle (Saale), \\ Germany \\ *All authors contributed equally for this work
}

Correspondence to: Alexey Surov, email: Alexey.Surov@medizin.uni-leipzig.de

Keywords: DWI, MRI, ADC, cellularity, tumor

Received: March 31, 2017 Accepted: April 27, $2017 \quad$ Published: May 10, 2017

Copyright: Surov et al. This is an open-access article distributed under the terms of the Creative Commons Attribution License 3.0 (CC BY 3.0), which permits unrestricted use, distribution, and reproduction in any medium, provided the original author and source are credited.

\section{ABSTRACT}

The purpose of this meta-analysis was to provide clinical evidence regarding relationship between ADC and cellularity in different tumors based on large patient data.

Medline library was screened for associations between ADC and cell count in different tumors up to September 2016. Only publications in English were extracted. The Preferred Reporting Items for Systematic Reviews and Meta-Analyses statement (PRISMA) was used for the research.

Overall, 39 publications with 1530 patients were included into the analysis. The following data were extracted from the literature: authors, year of publication, number of patients, tumor type, and correlation coefficients.

The pooled correlation coefficient for all studies was $\rho=-0.56(95 \% \mathrm{CI}=[-0.62$; $-0.50])$,. Correlation coefficients ranged from $\rho=-0.25(95 \% \mathrm{CI}=[-0.63 ; 0.12])$ in lymphoma to $p=-0.66(95 \% \mathrm{CI}=[-0.85 ;-0.47])$ in glioma. Other coefficients were as follows: ovarian cancer, $\rho=-0.64(95 \% \mathrm{CI}=[-0.76 ;-0.52])$; lung cancer, $\rho=-0.63(95 \% \mathrm{CI}=[-0.78 ;-0.48])$; uterine cervical cancer, $\rho=-0.57(95 \%$ $\mathrm{CI}=[-0.80 ;-0.34]) ;$ prostatic cancer, $\rho=-0.56(95 \% \mathrm{CI}=[-0.69 ;-0.42])$; renal cell carcinoma, $\rho=-0.53(95 \% \mathrm{CI}=[-0.93 ;-0.13])$; head and neck squamous cell carcinoma, $\rho=-0.53(95 \% \mathrm{CI}=[-0.74 ;-0.32])$; breast cancer, $\rho=-0.48$ (95\% $\mathrm{CI}=[-0.74 ;-0.23]) ;$ and meningioma, $\rho=-0.45(95 \% \mathrm{CI}=[-0.73 ;-0.17])$.

\section{INTRODUCTION}

Diffusion weighted imaging (DWI) is a magnetic resonance imaging (MRI) technique based on measure of water diffusion in tissues [1]. Beside diagnostic potential, DWI

can distinguish malignant from benign lesions [2, 3]. As reported previously, malignant tumors showed lower apparent diffusion coefficient (ADC) values in comparison to benign lesions $[2,3]$.

According to the literature, DWI can also provide additional information about tissue microstructure [1, 4-6]. Experimental studies showed a strong association between ADC and cell count in vitro [4-6]. It has been shown that increase of cell density restricted water diffusion and decreased ADC [5, 6]. However, published data of clinical investigations were inconsistent. While some authors identified significant correlations between ADC and cellularity in different tumor, other did not [7-11]. Moreover, there was a wide spectrum of reported correlation coefficients ranging from 0.1 to -0.79 [7-12]. Furthermore, the number of investigated patients/tumors in most studies was up to 50 [7-12]. Only few reports analyzed relative large collectives ranging from 102 to 138 patients [13-16]. Therefore, the reported data cannot be considered as evident. Overall, these facts question the possibility to use ADC as a surrogate biomarker for cellularity in clinical practice. 
The purpose of this meta-analysis was to provide clinical evidence regarding relationship between ADC and cellularity in different tumors based on large patient data.

\section{RESULTS}

Overall, the pooled correlation coefficient for all studies (Figure 1) was $\rho=-0.56$, (95\% CI $=[-0.62$; $-0.50])$, heterogeneity $\tau^{2}=0.02,(p<0.00001), \mathrm{I}^{2}=67 \%$, test for overall effect $Z=18.01(p<0.00001)$.

On the next step, correlation coefficients for every tumor entities were calculated. For this analysis, only data for primary tumors were acquired (Figure 2). The calculated correlation coefficients ranged from $\rho=-0.25(95 \% \mathrm{CI}=$ $[-0.63 ; 0.12])$ in lymphoma to $\rho=-0.66(95 \% \mathrm{CI}=[-0.85$;
$-0.47])$ in glioma. Other coefficients were as follows: ovarian cancer, $\rho=-0.64(95 \% \mathrm{CI}=[-0.76 ;-0.52])$; lung cancer, $\rho=-0.63(95 \% \mathrm{CI}=[-0.78 ;-0.48])$; uterine cervical cancer, $\rho=-0.57(95 \% \mathrm{CI}=[-0.80 ;-0.34])$; prostatic cancer, $\rho=-0.56(95 \% \mathrm{CI}=[-0.69 ;-0.42])$; renal cell carcinoma, $\rho=-0.53(95 \% \mathrm{CI}=[-0.93 ;-0.13])$; head and neck squamous cell carcinoma (HNSCC), $\rho=-0.53$ (95\% CI = $[-0.74 ;-0.32])$; breast cancer, $\rho=-0.48(95 \% \mathrm{CI}=[-0.74$; $-0.23])$; meningioma, $\rho=-0.45(95 \% \mathrm{CI}=[-0.73 ;-0.17])$.

\section{DISCUSSION}

The present analysis provides evidence regarding correlation between $\mathrm{ADC}$, in particular $\mathrm{ADC}_{\text {mean }}$, and cellularity in different tumors based on a large sample.

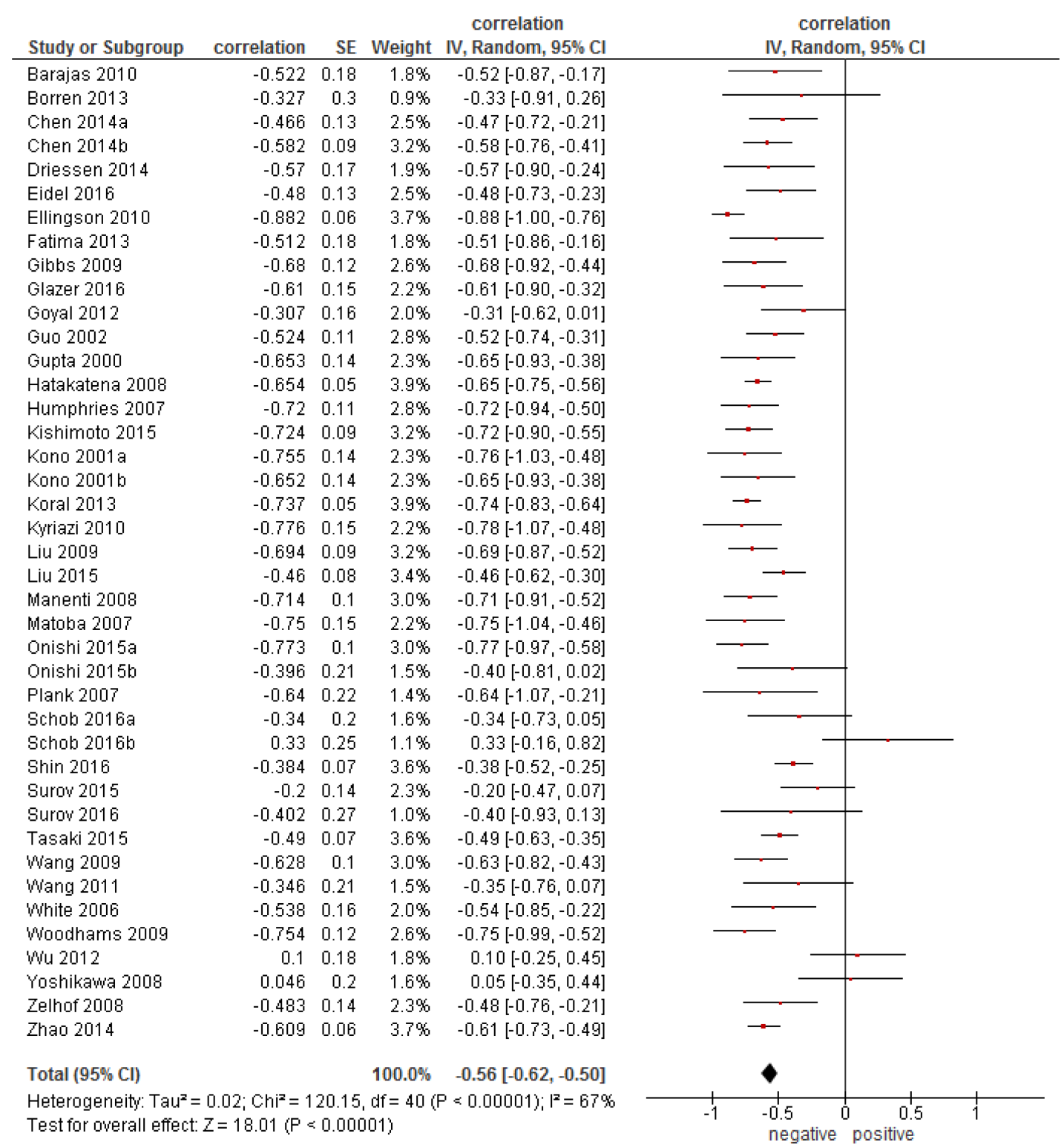

Figure 1: Forest plots of correlation coefficients between $\mathrm{ADC}_{\mathrm{m}}$ studies. 
Previously, numerous studies investigated associations between ADC and cell density in several tumors [7-46]. Overall, most reports showed significant correlations between these parameters $[7,9,15,16,21,32$, $33,41,43]$. So, Woodhams et al. found a strong inverse correlation $(\rho=-0.75, p=0.001)$ between ADC and cell count in mucinous breast carcinoma [43]. Based on the reported data, it has been postulated that DWI, namely $\mathrm{ADC}$ is an imaging tool to estimate tumor cellularity [43].
However, there were also reports, in which no significant correlations between ADC values and cell count were found $[11,38]$. For example, in different lymphomas, the correlation coefficient between cell count and ADC was $\rho=0.1(p=0.58)[10]$. Similar negative results were published for head and neck carcinoma $(\rho=-0.418, p=$ 0.201 ) [39], meningioma ( $\rho=-0.20, p=0.164)$ [38], and breast cancer $(\rho=0.048, p=0.812)$ [11]. Some previous reports attempted to explain their negative

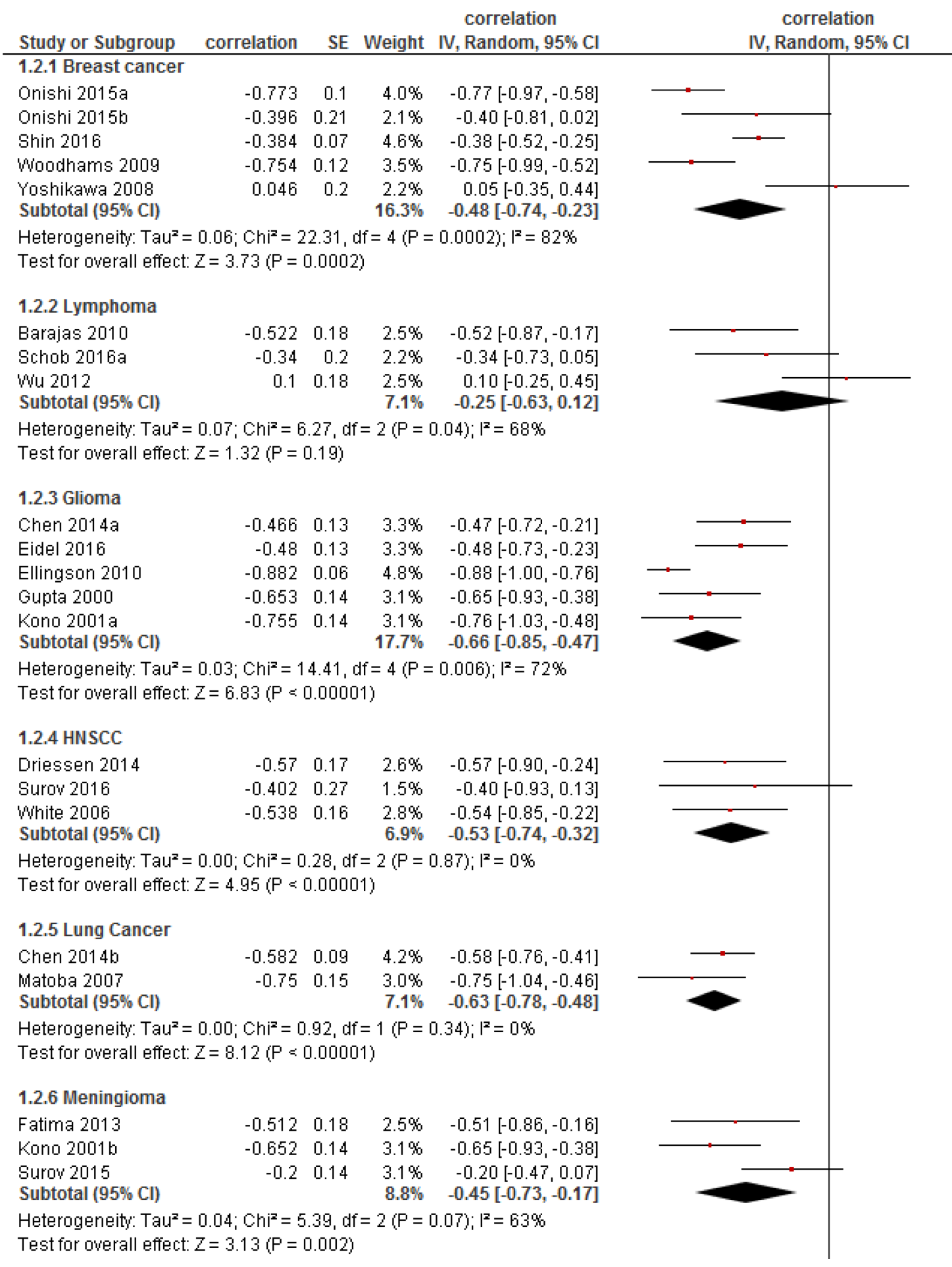




\subsubsection{Ovarian cancer}

Kyriazi 2010

Zhao 2014

Subtotal $(95 \% \mathrm{Cl})$

Heterogeneity: $\operatorname{Tau}^{2}=0.00 ; \mathrm{Ch}^{2}=1.07, \mathrm{df}=1(\mathrm{P}=0.30) ; \mathrm{I}^{2}=6 \%$

Test for overall effect: $Z=10.36$ ( $P=0.00001)$

\subsubsection{Prostatic cancer}

Borren 2013

Gibbs 2009

Glazer 2016

Wang 2011

Zelhof 2008

Subtotal $(95 \% \mathrm{Cl})$

Heterogeneity: $\mathrm{Tau}^{2}=0.00 ; \mathrm{Chi}^{2}=3.05, \mathrm{df}=4(\mathrm{P}=0.55) ; \mathrm{I}^{2}=0 \%$

Test for overall effect: $Z=7.84(\mathrm{P}=0.00001)$

\subsubsection{Renal cell carcinoma}

Goyal 2012

Manenti 2008

$-0.307 \quad 0.16$

$2.8 \%$

Subtotal $(95 \% \mathrm{Cl})$

$-0.714 \quad 0.1$

$4.0 \%$

Heterogeneity: Tau $^{2}=0.07 ; \mathrm{Chi}^{2}=4.65, \mathrm{df}=1(\mathrm{P}=0.03) ; \mathrm{I}^{2}=79 \%$

Test for overall effect: $Z=2.61(\mathrm{P}=0.009)$

\subsubsection{Uterine cervical cancer}

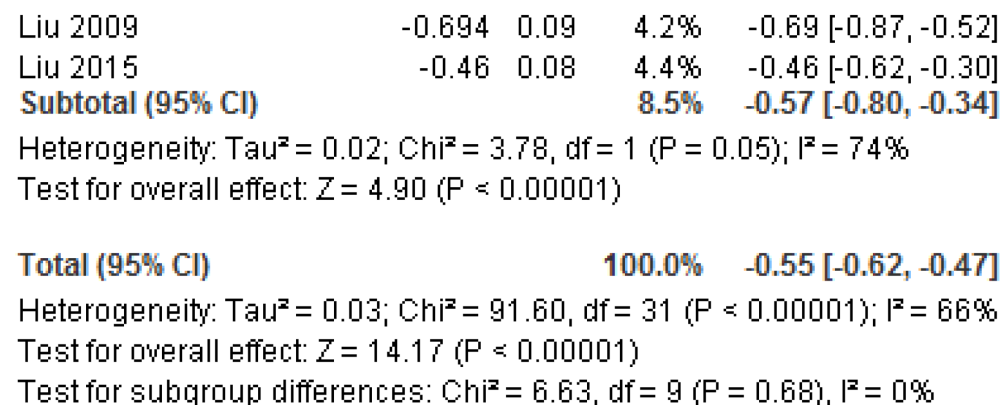

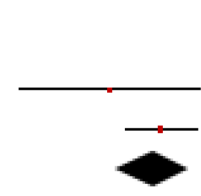

$-0.33[-0.91,0.26]$

$-0.68[-0.92,-0.44]$

$-0.61[-0.90,-0.32]$

$-0.35[-0.76,0.07]$

$-0.48[-0.76,-0.21]$

$-0.56[-0.69,-0.42]$

$-0.31[-0.62,0.01]$

$-0.71[-0.91,-0.52]$

$-0.53[-0.93,-0.13]$

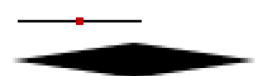

Figure 2: Forest plots of correlation coefficients between ADCmean and cellularity in different primary tumors.

findings by small number of patients [37, 39]. However, another cause of the controversial results in the literature is possible. Presumably, different tumors may have also different associations between ADC and tumor cell count. Our results confirmed this assumption. As seen, ADC showed a moderate inverse correlation with cellularity in the general collective. However, this finding did not apply for each tumor entity, and, therefore, cannot be used in clinical practice. We found that the correlation ADC vs cellularity ranged significantly in different tumors. It was weak in lymphomas, weak-to-moderate in breast cancer and meningiomas, moderate in most investigated epithelial tumors, and strong in gliomas, ovarian cancer, and lung cancer. It is still unclear, why ADC correlates well with cell count in some tumors, whereas in other does not. Presumably, not only cell count, but also other histopathological features, such as extracellular matrix, nucleic areas, ratio stroma/parenchyma, and /or microvessel density may play a role here. In fact, some studies found statistically significant associations between nucleic size and ADC in several lesions [46, 47]. Overall, our findings suggest that ADC does not reflect cellularity in all tumors.

Our analysis also identified another problem. There are no reports regarding associations between $\mathrm{ADC}$ and cellularity in most gastrointestinal tumors: esophageal cancer, gastric cancer, colorectal carcinoma, gastrointestinal stromal tumors, hepatocellular carcinoma, pancreatic carcinomas, and gall bladder cancer. Also in malignancies of cutis, such as malignant melanoma, no reports about $\mathrm{ADC} /$ cell count could be identified. Except renal cell carcinoma and prostatic cancer, no data exist for urological malignancies. In addition, several tumors involved into the present meta-analysis, for 
Table 1: Patients involved into the study

\begin{tabular}{lll}
\hline Diagnosis & $\mathbf{n}$ & $\mathbf{\%}$ \\
\hline Different breast tumors & 402 & 26.28 \\
Different brain tumors & 318 & 20.78 \\
Uterine muscle sarcoma & 134 & 8.76 \\
Uterine cervical cancer & 130 & 8.50 \\
Prostatic cancer & 119 & 7.78 \\
Ovarian cancer & 110 & 7.19 \\
Lymphoma & 71 & 4.64 \\
Lung cancer & 69 & 4.51 \\
Renal cell carcinoma & 59 & 3.86 \\
HNSCC & 48 & 3.14 \\
Endometrial cancer & 30 & 1.96 \\
Pancreatic neuroendocrine tumor & 18 & 1.18 \\
Thyroid cancer & 14 & 0.92 \\
Spinal epidural tumors & 8 & 0.52 \\
Total & $\mathbf{1 5 3 0}$ & $\mathbf{1 0 0}$ \\
\hline
\end{tabular}

HNSCC, head and neck squamous cell carcinoma

example, HNSCC, renal cell carcinoma, lung cancer, and lymphomas contained small number of patients. This relativizes the calculated results. Finally, for some tumors, such as pancreatic neuroendocrine carcinoma [41], soft tissue sarcomas [15], and thyroid cancer [37], only one report was published, respectively. Therefore, no evident data could be estimated for these entities. Clearly, further researches are needed to investigate possible associations between ADC and cellularity in these tumors. Thereafter, a similar meta-analysis is also needed to prove new data.

In conclusion, different inverse correlations were identified between ADC and cell count in the analyzed tumors. ADC correlated strongly with cell count in gliomas, followed by ovarian cancer, and lung cancer. Therefore, in these tumors, ADC can be used as an imaging marker to estimate cellularity. Moderate inverse correlations were identified between ADC and cell count in prostatic cancer, renal cell carcinoma, uterine cervical cancer, and head/neck squamous cell carcinomas.

Furthermore, weak-to-moderate correlations were found in breast cancer and meningioma. This finding relativizes the possibility of ADC use to predict cellularity in these tumors. Finally, weak correlation was identified in lymphomas. Therefore, ADC cannot be used as a cellularity biomarker in this entity.

No evident data can be provided to date for other malignancies.

\section{MATERIALS AND METHODS}

\section{Data acquisition and proving}

MEDLINE library was screened for associations between ADC and cell count in different tumors up to September 2016. The following search words were used: "DWI or diffusion weighted imaging or diffusion-weighted imaging or ADC or apparent diffusion coefficient AND cellularity or cell density or cell count or cell number". Only publications in English were extracted. The Preferred Reporting Items for Systematic Reviews and Meta-Analyses statement (PRISMA) was used for the research [48].

After exclusion of duplicates, a total of 494 publications was identified. These reports were involved into the further analysis. For this work, only data regarding $\mathrm{ADC}_{\text {mean }}$ derived from diffusion weighted imaging (DWI) were acquired. Papers which did not contain correlation coefficients between ADC and cell count were excluded. In addition, data retrieved from diffusion tensor imaging and other DWI parameters, such as $\mathrm{D}, \mathrm{ADC}_{\max }$, and $\mathrm{ADC}_{\min }$ were also excluded. Finally, we excluded experimental animals and in vitro studies. Overall, 455 publications were excluded. Therefore, the present analysis comprises 39 publications with 1530 patients [7-46]. The following data were extracted from the literature: authors, year of publication, number of patients, tumor type, and correlation coefficients. Most frequently, different breast, followed by several brain tumors, uterine sarcomas, uterine cervical cancer, prostatic cancer,and ovarian cancer were reported (Table 1). Other tumors were rarer.

\section{Meta-analysis}

The methodological quality of the 39 included studies was independently checked by two observers (A.S. and H.J.M.) using the Quality Assessment of Diagnostic Studies (QUADAS) instrument according to previous descriptions [49, 50]. The results of QUADAS proving are shown in Table 2.

Spearman's correlation coefficient was used to analyze associations between $\mathrm{ADC}_{\text {mean }}$ and cell count. The reported Pearson correlation coefficients in some publications were converted into Spearman correlation coefficients as reported previously [51]. 
Table 2: Methodological quality of the involved 39 studies according to the QUADAS criteria

\begin{tabular}{lccc}
\hline & Yes (\%) & No (\%) & Unclear (\%) \\
\hline Patient spectrum & $24(61.54)$ & $8(20.51)$ & $7(17.95)$ \\
Selection criteria & $25(64.10)$ & $10(25.64)$ & $4(10.26)$ \\
Reference standard & $39(100)$ & & \\
Disease progression bias & $39(100)$ & & \\
Partial verification bias & $39(100)$ & & \\
Differential verification bias & $39(100)$ & & \\
Incorporation bias & $39(100)$ & & \\
Text details & $39(100)$ & & \\
Reference standard details & $39(100)$ & $9(20.51)$ & $13(33.33)$ \\
Text review details & $18(46.15)$ & & $12(30.77)$ \\
Diagnostic review bias & $18(46.15)$ & & $1(2.56)$ \\
Clinical review bias & $38(97.44)$ & & $1(2.56)$ \\
Uninterpretable results & $38(97.44)$ & & $1(2.56)$ \\
Withdrawals explained & $38(97.44)$ & & \\
\hline
\end{tabular}

The meta-analysis was undertaken by using RevMan 5.3. Heterogeneity was calculated by means of the inconsistency index $\mathrm{I}^{2}[52,53]$. In a subgroup analysis studies were stratified by tumor type. Furthermore, DerSimonian and Laird random-effects models with inverse-variance weights were used without any further correction [54].

\section{REFERENCES}

1. Fornasa F. Diffusion-weighted Magnetic Resonance Imaging: What Makes Water Run Fast or Slow? J Clin Imaging Sci. 2011; 1:27.

2. Wang J, Takashima S, Takayama F, Kawakami S, Saito A, Matsushita T, Momose M, Ishiyama T. Head and neck lesions: characterization with diffusion-weighted echoplanar MR imaging. Radiology. 2001; 220:621-30.

3. Sasaki M, Eida S, Sumi M, Nakamura T. Apparent diffusion coefficient for sinonasal diseases: differentiation of benign and malignant lesions. AJNR Am J Neuroradiol. 2011; 32:1100-06.

4. Xu J, Does MD, Gore JC. Sensitivity of MR diffusion measurements to variations in intracellular structure: effects of nuclear size. Magn Reson Med. 2009; 61:828-33.

5. Galons JP, Lope-Piedrafita S, Divijak JL, Corum C, Gillies RJ, Trouard TP. Uncovering of intracellular water in cultured cells. Magn Reson Med. 2005; 54:79-86.

6. Harkins KD, Galons JP, Secomb TW, Trouard TP. Assessment of the effects of cellular tissue properties on ADC measurements by numerical simulation of water diffusion. Magn Reson Med. 2009; 62:1414-22.

7. Barajas RF Jr, Rubenstein JL, Chang JS, Hwang J, Cha S. Diffusion-weighted MR imaging derived apparent diffusion coefficient is predictive of clinical outcome in primary central nervous system lymphoma. AJNR Am J Neuroradiol. 2010; 31:60-66.

8. Borren A, Moman MR, Groenendaal G, Boeken Kruger AE, van Diest PJ, van der Groep P, van der Heide UA, van Vulpen M, Philippens ME. Why prostate tumour delineation based on apparent diffusion coefficient is challenging: an exploration of the tissue microanatomy. Acta Oncol. 2013; 52:1629-36.

9. Driessen JP, Caldas-Magalhaes J, Janssen LM, Pameijer FA, Kooij N, Terhaard CH, Grolman W, Philippens ME. Diffusion-weighted MR imaging in laryngeal and hypopharyngeal carcinoma: association between apparent diffusion coefficient and histologic findings. Radiology. 2014; 272:456-63.

10. Wu X, Pertovaara $\mathrm{H}$, Dastidar $\mathrm{P}$, Vornanen $\mathrm{M}$, Paavolainen L, Marjomäki V, Järvenpää R, Eskola H, Kellokumpu-Lehtinen PL. ADC measurements in diffuse large B-cell lymphoma and follicular lymphoma: a DWI and cellularity study. Eur J Radiol. 2013; 82:e158-64.

11. Yoshikawa MI, Ohsumi S, Sugata S, Kataoka M, Takashima S, Mochizuki T, Ikura H, Imai Y. Relation between cancer cellularity and apparent diffusion coefficient values using diffusion-weighted magnetic resonance imaging in breast cancer. Radiat Med. 2008; 26:222-26.

12. Ellingson BM, Malkin MG, Rand SD, Connelly JM, Quinsey C, LaViolette PS, Bedekar DP, Schmainda KM. Validation of functional diffusion maps (fDMs) as a biomarker for human glioma cellularity. J Magn Reson Imaging. 2010; 31:538-48.

13. Hatakenaka M, Soeda H, Yabuuchi H, Matsuo Y, Kamitani T, Oda Y, Tsuneyoshi M, Honda H. Apparent diffusion coefficients of breast tumors: clinical application. Magn Reson Med Sci. 2008; 7:23-29. 
14. Shin HJ, Kim SH, Lee HJ, Gong G, Baek S, Chae EY, Choi WJ, Cha JH, Kim HH. Tumor apparent diffusion coefficient as an imaging biomarker to predict tumor aggressiveness in patients with estrogen-receptor-positive breast cancer. NMR Biomed. 2016; 29:1070-78.

15. Tasaki A, Asatani MO, Umezu H, Kashima K, Enomoto T, Yoshimura N, Aoyama H. Differential diagnosis of uterine smooth muscle tumors using diffusion-weighted imaging: correlations with the apparent diffusion coefficient and cell density. Abdom Imaging. 2015; 40:1742-52.

16. Zhao SH, Qiang JW, Zhang GF, Ma FH, Cai SQ, Li HM, Wang L. Diffusion-weighted MR imaging for differentiating borderline from malignant epithelial tumours of the ovary: pathological correlation. Eur Radiol. 2014; 24:2292-99.

17. Chen L, Zhang J, Chen Y, Wang W, Zhou X, Yan X, Wang J. Relationship between apparent diffusion coefficient and tumour cellularity in lung cancer. PLoS One. 2014; 9:e99865.

18. Eidel O, Neumann JO, Burth S, Kieslich PJ, Jungk C, Sahm F, Kickingereder P, Kiening K, Unterberg A, Wick W, Schlemmer HP, Bendszus M, Radbruch A. Automatic Analysis of Cellularity in Glioblastoma and Correlation with ADC Using trajectory analysis and automatic nuclei counting. PLoS One. 2016; 11:e0160250.

19. Fatima Z, Motosugi U, Waqar AB, Hori M, Ishigame K, Oishi N, Onodera T, Yagi K, Katoh R, Araki T. Associations among q-space MRI, diffusion-weighted MRI and histopathological parameters in meningiomas. Eur Radiol. 2013; 23:2258-63.

20. Gibbs P, Liney GP, Pickles MD, Zelhof B, Rodrigues G, Turnbull LW. Correlation of ADC and T2 measurements with cell density in prostate cancer at 3.0 Tesla. Invest Radiol. 2009; 44:572-76.

21. Glazer DI, Hassanzadeh E, Fedorov A, Olubiyi OI, Goldberger SS, Penzkofer T, Flood TA, Masry P, Mulkern RV, Hirsch MS, Tempany CM, Fennessy FM. Diffusion-weighted endorectal MR imaging at $3 \mathrm{~T}$ for prostate cancer: correlation with tumor cell density and percentage Gleason pattern on whole mount pathology. Abdom Radiol (NY). 2017; 42:918-25.

22. Goyal A, Sharma R, Bhalla AS, Gamanagatti S, Seth A, Iyer VK, Das P. Diffusion-weighted MRI in renal cell carcinoma: a surrogate marker for predicting nuclear grade and histological subtype. Acta Radiol. 2012; 53:349-58.

23. Guo Y, Cai YQ, Cai ZL, Gao YG, An NY, Ma L, Mahankali S, Gao JH. Differentiation of clinically benign and malignant breast lesions using diffusion-weighted imaging. J Magn Reson Imaging. 2002; 16:172-78.

24. Gupta RK, Cloughesy TF, Sinha U, Garakian J, Lazareff J, Rubino G, Rubino L, Becker DP, Vinters HV, Alger JR. Relationships between choline magnetic resonance spectroscopy, apparent diffusion coefficient and quantitative histopathology in human glioma. J Neurooncol. 2000; 50:215-26.
25. Humphries PD, Sebire NJ, Siegel MJ, Olsen ØE. Tumors in pediatric patients at diffusion-weighted MR imaging: apparent diffusion coefficient and tumor cellularity. Radiology. 2007; 245:848-54.

26. Kishimoto K, Tajima S, Maeda I, Takagi M, Ueno T, Suzuki N, Nakajima Y. Endometrial cancer: correlation of apparent diffusion coefficient (ADC) with tumor cellularity and tumor grade. Acta Radiol. 2016; 57:1021-28.

27. Kono K, Inoue Y, Nakayama K, Shakudo M, Morino M, Ohata K, Wakasa K, Yamada R. The role of diffusionweighted imaging in patients with brain tumors. AJNR Am J Neuroradiol. 2001; 22:1081-88.

28. Koral K, Mathis D, Gimi B, Gargan L, Weprin B, Bowers DC, Margraf L. Common pediatric cerebellar tumors: correlation between cell densities and apparent diffusion coefficient metrics. Radiology. 2013; 268:532-37.

29. Kyriazi S, Nye E, Stamp G, Collins DJ, Kaye SB, deSouza NM. Value of diffusion-weighted imaging for assessing site-specific response of advanced ovarian cancer to neoadjuvant chemotherapy: correlation of apparent diffusion coefficients with epithelial and stromal densities on histology. Cancer Biomark. 2010; 7:201-10.

30. Liu Y, Bai R, Sun H, Liu H, Wang D. Diffusion-weighted magnetic resonance imaging of uterine cervical cancer. $\mathrm{J}$ Comput Assist Tomogr. 2009; 33:858-62.

31. Liu Y, Ye Z, Sun H, Bai R. Clinical Application of Diffusion-weighted magnetic resonance imaging in uterine cervical cancer. Int J Gynecol Cancer. 2015; 25:1073-78.

32. Manenti G, Di Roma M, Mancino S, Bartolucci DA, Palmieri G, Mastrangeli R, Miano R, Squillaci E, Simonetti G. Malignant renal neoplasms: correlation between ADC values and cellularity in diffusion weighted magnetic resonance imaging at $3 \mathrm{~T}$. Radiol Med (Torino). 2008; 113:199-213.

33. Matoba M, Tonami H, Kondou T, Yokota H, Higashi K, Toga H, Sakuma T. Lung carcinoma: diffusion-weighted mr imaging - preliminary evaluation with apparent diffusion coefficient. Radiology. 2007; 243:570-77.

34. Onishi N, Kanao S, Kataoka M, Iima M, Sakaguchi R, Kawai M, Kataoka TR, Mikami Y, Toi M, Togashi K. Apparent diffusion coefficient as a potential surrogate marker for Ki-67 index in mucinous breast carcinoma. J Magn Reson Imaging. 2015; 41:610-15.

35. Plank C, Koller A, Mueller-Mang C, Bammer R, Thurnher MM. Diffusion-weighted MR imaging (DWI) in the evaluation of epidural spinal lesions. Neuroradiology. 2007; 49:977-85.

36. Schob S, Meyer J, Gawlitza M, Frydrychowicz C, Müller W, Preuss M, Bure L, Quäschling U, Hoffmann KT, Surov A. Diffusion-Weighted MRI reflects proliferative activity in primary CNS Lymphoma. PLoS One. 2016; 11:e0161386.

37. Schob S, Voigt P, Bure L, Meyer HJ, Wickenhauser C, Behrmann C, Höhn A, Kachel P, Dralle H, Hoffmann KT, 
Surov A. Diffusion-Weighted imaging using a readoutsegmented, multishot EPI sequence at $3 \mathrm{~T}$ distinguishes between morphologically differentiated and undifferentiated subtypes of thyroid carcinoma-a preliminary study. Transl Oncol. 2016; 9:403-10.

38. Surov A, Gottschling S, Mawrin C, Prell J, Spielmann RP, Wienke A, Fiedler E. Diffusion-weighted imaging in meningioma: prediction of tumor grade and association with histopathological parameters. Transl Oncol. 2015; 8:517-23.

39. Surov A, Stumpp P, Meyer HJ, Gawlitza M, Höhn AK, Boehm A, Sabri O, Kahn T, Purz S. Simultaneous (18) F-FDG-PET/MRI: associations between diffusion, glucose metabolism and histopathological parameters in patients with head and neck squamous cell carcinoma. Oral Oncol. 2016; 58:14-20.

40. Wang XZ, Wang B, Gao ZQ, Liu JG, Liu ZQ, Niu QL, Sun ZK, Yuan YX. Diffusion-weighted imaging of prostate cancer: correlation between apparent diffusion coefficient values and tumor proliferation. J Magn Reson Imaging. 2009; 29:1360-66.

41. Wang Y, Chen ZE, Yaghmai V, Nikolaidis P, McCarthy RJ, Merrick L, Miller FH. Diffusion-weighted MR imaging in pancreatic endocrine tumors correlated with histopathologic characteristics. J Magn Reson Imaging. 2011; 33:1071-79.

42. White ML, Zhang Y, Robinson RA. Evaluating tumors and tumorlike lesions of the nasal cavity, the paranasal sinuses, and the adjacent skull base with diffusion-weighted MRI. J Comput Assist Tomogr. 2006; 30:490-95.

43. Woodhams R, Kakita S, Hata H, Iwabuchi K, Umeoka S, Mountford CE, Hatabu H. Diffusion-weighted imaging of mucinous carcinoma of the breast: evaluation of apparent diffusion coefficient and signal intensity in correlation with histologic findings. AJR Am J Roentgenol. 2009; 193:260-66.

44. Zelhof B, Pickles M, Liney G, Gibbs P, Rodrigues G, Kraus S, Turnbull L. Correlation of diffusion-weighted magnetic resonance data with cellularity in prostate cancer. BJU Int. 2009; 103:883-88.

45. Chen SD, Hou PF, Lou L, Jin X, Wang TH, Xu JL. The correlation between MR diffusion-weighted imaging and pathological grades on glioma. Eur Rev Med Pharmacol Sci. 2014; 18:1904-09.
46. Langer DL, van der Kwast TH, Evans AJ, Plotkin A, Trachtenberg J, Wilson BC, Haider MA. Prostate tissue composition and MR measurements: investigating the relationships between $\mathrm{ADC}, \mathrm{T} 2, \mathrm{~K}($ trans), $\mathrm{v}(\mathrm{e})$, and corresponding histologic features. Radiology. 2010; 255:485-94.

47. Surov A, Caysa H, Wienke A, Spielmann RP, Fiedler E. Correlation between different ADC fractions, cell count, $\mathrm{Ki}-67$, total nucleic areas and average nucleic areas in meningothelial meningiomas. Anticancer Res. 2015; 35:6841-46.

48. Moher D, Liberati A, Tetzlaff J, Altman DG, PRISMA Group. Preferred reporting items for systematic reviews and meta-analyses: the PRISMA statement. PLoS Med. 2009; 6:e1000097.

49. Whiting P, Rutjes AW, Reitsma JB, Bossuyt PM, Kleijnen J. The development of QUADAS: a tool for the quality assessment of studies of diagnostic accuracy included in systematic reviews. BMC Med Res Methodol. 2003; 3:25.

50. Whiting PF, Weswood ME, Rutjes AW, Reitsma JB, Bossuyt PN, Kleijnen J. Evaluation of QUADAS, a tool for the quality assessment of diagnostic accuracy studies. BMC Med Res Methodol. 2006; 6:9.

51. Chalkidou A, Landau DB, Odell EW, Cornelius VR, O’Doherty MJ, Marsden PK. Correlation between Ki-67 immunohistochemistry and 18F-fluorothymidine uptake in patients with cancer: A systematic review and metaanalysis. Eur J Cancer. 2012; 48:3499-513.

52. Leeflang MM, Deeks JJ, Gatsonis C, Bossuyt PM, Cochrane Diagnostic Test Accuracy Working Group. Systematic reviews of diagnostic test accuracy. Ann Intern Med. 2008; 149:889-97.

53. Zamora J, Abraira V, Muriel A, Khan K, Coomarasamy A. Meta-DiSc: a software for meta-analysis of test accuracy data. BMC Med Res Methodol. 2006; 6:31.

54. DerSimonian R, Laird N. Meta-analysis in clinical trials. Control Clin Trials. 1986; 7:177-88. 